\title{
Behavioural Adaptation of Malay Families and Housing Modification of Terrace Houses in Malaysia
}

\author{
Zaiton Abdul Rahim ${ }^{1}$, Ahmad Hariza Hashim² \\ ${ }^{1}$ Faculty of Architecture and Environmental Design, International Islamic University Malaysia, Malaysia \\ ${ }^{2}$ Faculty of Human Ecology, Universiti Putra Malaysia, Malaysia \\ zaitonOiiu.edu.my
}

\begin{abstract}
This paper examines the behavioural adaptation of Malay families living in terrace houses with regards to the activity system, privacy and social interaction among Malay families and terrace housing modification. 7he study uses case studies of 11 Malay families living in the three-bedroom two-storey terrace houses in two urban locations in Malaysia. Findings indicate that behavioural adaptation resulted in changes in some aspects of the Malay culture and housing modifications provided a more supportive living environment but have adverse effects on individual family and housing community due to the constraints of the terrace housing design.
\end{abstract}

Keywords: behavioural adaptation; housing modification; privacy; social interaction.

eISSN ISSN 2514-751X @ 2018. The Authors. Published for AMER ABRA cE-Bs by e-International Publishing House, Ltd., UK. This is an open-access article under the CC BY-NC-ND license (http://creativecommons.org/licenses/by-nc-nd/4.0/). Peer-review under responsibility of AMER (Association of Malaysian Environment-Behaviour Researchers), ABRA (Association of Behavioural Researchers on Asians) and $c E-B s$ (Centre for Environment-Behaviour Studies), Faculty of Architecture, Planning \& Surveying, Universiti Teknologi MARA, Malaysia.

DOI: https://doi.org/10.21834/aje-bs.v3i6.235 


\subsection{Introduction}

There are different opinions on the relationship between culture and behaviour. Some authors argue that culture influence the environment while others argue the opposite. Despite the differences in opinion, extant literature has indicated the link and relationship between behaviour and environment (Baron, Robert \& Byrne, 1991; Betchtel, 1997; Rivlin, 2000; Wapner, Demick, Yamamoto \& Minami, 2000). Altman (1975) posited that the environment is both "a determinant of behaviour and an extension of behaviour". The relationship between environment and social behaviour is anactiveand continuousprocess of interacting and interrelated components. It is not a direct causal sequence, but one of reciprocal or circular feedback whereby each component is both a cause and effect. It not only acts upon other components and thereby changes them, but in so doing it changes the environment and thereby induces changes in itself (Franck, 1985).

Rapoport and Hardie (1991) suggest that culture changes in tandem with built environment. This suggestion is relevant when the built environment is meant for a homogeneous group of people who have control over the built environment such as seen in the traditional society. However, the suggestion may not be applicable when housing was imposed on the people and when it is not consistent with their cultural needs and designed for a heterogeneous group of people with different cultures. In this case behavioural adaptation and physical modification are required. Proshansky, Ittelson and Rivlin (1970) suggested that changes in the characteristic behaviour patterns of a physical setting can be induced by the physical settings. Archea (1977) suggested that social behaviours are involved in settings whose objective and physical characteristics have the potential to affect the behaviour itself. In the case of the house, it has the potential to influence the behavioural pattern of the family particularly the activity system, privacy and social interaction.

Environment can either facilitate or inhibit certain behaviours, cognitive processes, mood and so on (Rapoport, 2005). Behaviour in relation to a physical setting is dynamically organised. Specific behaviours adapt to environmental constraints to create necessary equilibrium between the individual and his environment (Leboyer, 1982). Behavioural adaptation may result in negative consequences unless it is healthy or at least not harmful. There are claims that the built environment is a determinant of behaviour whereby behavioural adaptation is a spontaneous response to constraints in the environment(Archea, 1977; Proshansky, Ittelson \& Rivlin, 1970). Ahmad Hariza \& Zaiton (2006) found that housing designs which were not consistent with the culture of the people resulted in changes in behavioural patterns and aspects of culture, an indirect effect of the built environment on culture. Hanson \& Hanson (1993) noted that the physical environment imposes constraints on feasible activities. A physical setting not conducive to a pattern of behaviour which has been characteristic of the setting will result in changes in the physical setting and adaptation in the characteristics of the behavioural pattern (Proshansky et al., 1970). The house is the most likely physical setting to be modified when it is not consistent with the needs and expected behavioural patterns of the family. The failure of the house to support the individual and collective needs of the family will result in behavioural adaptation to compensate for the 
environmental constraints or create a social environment replacing or completing what the physical environment provides for as suggested by Proshansky et al. (1970).

\section{Background}

Rapid changes in living conditions and contradictions between the global and Eastern world culture and local traditions have created new paradigms and changed culture-housing interactions in Malaysia. Housing designs in the country were and are influenced by foreign cultures. The designs are to a certain extent not consistent with the way of the life of the people. Most Malaysians in the urban areas rely on mass housing particularly terrace housings which dominate the housing supply in the urban areas. This type of housing introduced by the British in the 1960s is the most popular housing alternative and affordable to people from different level of income. The Western influenced housing designs are not based on the culture of the locals such as the Malays. At times, this contradiction indirectly affects some aspects of the Malay culture as shown by previous studies (Fatimah, 1994 and Yaakob, 1992). Behavioural adaptation and housing modifications of terrace houses can be seen as manifestation of the inconsistency between housing design and the culture of the people.

Ideally, housing designs support the overall needs of the family including the activity system, privacy and social interaction consistent with the culture of the people. However, to varying degrees, the physical constraints of the terrace houses may not be consistent with these needs. It was postulated that constraints imposed by building, foster psychological stress and impinge on one's felt sense of privacy by virtue of the behavioural adaptations that they necessitate, affecting all of those living in it (Booth, Edwards \& Edwards, 1982). The house should support daily activity systems for normal functioning of individuals and family, affords some degree of control over the physical environment and promotes social interactions between neighbours. However, the terrace housing designs are not consistent to the Malay culture as noted by some authors (Lim, 1987; Vlatseas, 1990; Mohamad Tajudin, 2003). Therefore behavioural adaptations are expected to create a balance between behaviour and the physical environment at least until housing modification can be afforded.

Housing modification is an expression of a resident's personality, tastes, interest, lifestyle, values and social status (Rapoport, 1981 \& Nasar, 1989). However, there are some social aspects that should be considered, particularly the cultural context of these studies especially in cases where the existing houses have not satisfied the important needs of the family. In these cases, modification was mainly to provide what was lacking in the existing house. In Malaysia, housing mobility in the urban areas is not a popular choice due to the high price of houses and strong neighbourhood attachment. Therefore, most people adapted to the terrace houses until modification can be afforded. Modification of terrace houses is widespread and become part of the Malaysian culture.

\section{Objectives}

Specifically, the objectives of the study are: 
1. To examine the behavioural adaptation in relation to activity system, privacy and social interaction

2. To examine the specifics of terrace housing modifications and effects on the Malay family and community

\subsection{Methodology}

The research uses case study employing personal interview, observation and analytical review of drawings (plans and elevations of housing units). The case studies involved eleven Malay households living in the two-storey three bedroom terrace houses in two urban areas namely in Kajang and KualaLumpur. The houses selected represent the smallest (seven cases) and the biggest two-storey three bedroom terrace houses (four cases) with different designs and layouts. The respondents for the study were identified during the first phase of the study which involved a survey interview of 401 . Only 22 respondents agreed to be interviewed. The respondents were selected based on their willingness to be interviewed. It is their relevance to the research topic rather than their representative-ness, which determines the ways in which the people to be studied are selected in qualitative research (Flick, 1998). This study uses the second rule proposed by Lonner and Berry (1986), whereby one does the best one can under the circumstances to appropriate a sample, which permits the proper execution of the research.

Selection of respondents was made based on the information on the background of the respondents gathered from the questionnaires. The selection of respondents was made to include these factors as there are many factors which influence activity system, privacy and social interaction of the family at home such as family size, gender and age of children, family life cycle and housing design. Across the samples, the respondents' views were explored in depth pertaining to the activity system, privacy and social interaction based on a prepared list of questions. A simple form was designed to ease the process of interviewing and to ensure that all respondents were asked the same questions. All interviews were fully transcribed for analysis. Respondents are from families with both female and male children, female children only, male children only and children of different ages. Each of the interviews took between 45 to 60 minutes. The interviews were recorded and transcribed. Photographs and sketches were used to record the physical changes but not all respondents allowed the internal part of their houses to be photographed.

\subsection{Findings and Discussions}

The discussions on findings are divided into three parts based on the objectives of the paper:

\section{Behavioural adaptation among Malay families living in three bedroom two-storey terrace houses}

Findings indicate that behavioural adaptation was most required to provide privacy at different levels in the activity systems and social interaction at both the public and private level. 
Specifically behavioural adaptation was needed to achieve visual privacy, to limit unwanted social interaction, to support daily activity system, parent's intimacy, seclusion for adolescent children and parents, separation of sleeping places and privacy in the presence of guests in the house. Behavioural adaptation was particularly required for families with both adolescent daughter(s) and son(s) due to the need to provide space for their daily activities such as reading and studying, separation of sleeping places and the need for solitude. In most cases, the living and dining were used for multiple activities at least until modification. Findings also indicate that sharing of bedrooms was common. The need for individual room did not arise as the children used to not having individual privacy early in their lives despite the increase in privacy needs as they reached adolescence. Findings indicate that the need to provide separation of sleeping places was consistent with Islamic requirement forseparate bedroom for the parents, daughters and sons for privacy. Increase in privacy need is associated with appropriation of space as suggested by Guiliani, Rullo and Bove (1990).

The lack of space in the terrace houses resulted in negative behavioural adaptation which was not consistent with the Malay cultural expectation in some cases such as entertaining male guests at the porch area instead of in the house to maintain the privacy of the family members. Most respondents also indicated the constraint of their houses prohibited them from having relatives spending the night at their houses contrary to the Malay cultural values whichemphasized on good hospitality given to guests especially relatives. Privacy at private level was not easily achieved in the presence of guests due to the openness of the ground floor which resulted in restricted use of the space in the presence of guests. Spaces such as dining and living area were used interchangeably but, at times, resulted in conflicts of usage.

Ten out of eleven respondents were in the opinion that behavioural adaptation was required to maintain privacy, unwanted social interaction and security. Locking the gate to the house and closing the door are common practices for these reasons which indirectly influenced the level of interaction with neighbours. The need to maintain own privacy and respect the neighbours' privacy indirectly resulted in less interaction with the neighbours. Most respondents appear to focus more on their family and interaction with neighbours was rarely on a daily basis. Living in close proximity of the terrace houses leads to loss of privacy and subsequently resulted in the tendency to compensate the lack of privacy due to physical constraint by reducing social interaction and spatial invasion through the use of territorial marker, which further discourages and limits social interaction among the neighbours. The finding was consistent with a study by Wong (2003) which finds that privacy at home is extremely important in Hong Kong compact living space. A strong emphasis on privacy creates barriers which limits interaction as people isolate themselves inside their own boundaries. Other behavioural adaptation include controlling noise from own houses, avoiding looking into the neighbour's house particularly when the house faces another housing unit and tolerance towards occasional intrusion within the neighbourhood. Table.1 summarises the design characteristics of the terrace houses which necessitate behavioural adaptation. 
Table 1: Terrace housing design characteristics which necessitate behavioural adaptation

\begin{tabular}{|c|c|c|}
\hline & Terrace housing design characteristics & Behavioural adaptation \\
\hline 1 & $\begin{array}{l}\text { Open layout, lack of a clear division } \\
\text { between public and private spaces and } \\
\text { proximity of spaces on the ground floor } \\
\text { affect the privacy of the family. }\end{array}$ & $\begin{array}{l}\text { - Guests were not invited into the house } \\
\text { to maintain privecy but entertained at } \\
\text { the porch area } \\
\text { - Restricted movement if guests were } \\
\text { invited into the house }\end{array}$ \\
\hline 2 & $\begin{array}{l}\text { Space constraint of ground floor and } \\
\text { bedrooms }\end{array}$ & $\begin{array}{l}\text { - Flexible use of public spaces such as } \\
\text { living and dining for many activities } \\
\text { which may resuled in conflict of usage } \\
\text { of these spaces }\end{array}$ \\
\hline 3 & $\begin{array}{l}\text { Three bedrooms are sufficient in } \\
\text { number but the third bedroom on the } \\
\text { gro und foor in some housing units is } \\
\text { inappropriatb. Some bedrooms are } \\
\text { awkward in configuration and bo small }\end{array}$ & $\begin{array}{l}\text { - Some respondents consider not } \\
\text { appropriate to have their young children } \\
\text { sleep on the ground floor. Therefore } \\
\text { young children share bedroom. In Islam, } \\
\text { separabion of bedroom for daughters } \\
\text { and son should take place once they } \\
\text { reach seven years oid. } \\
\text { - The children had to make do with } \\
\text { awkward bedroom by limiting activities } \\
\text { in the room } \\
\text { - Acceptance of the lack of individual } \\
\text { privecy from early age } \\
\text { - Limiting having sleep-over guests in the } \\
\text { house }\end{array}$ \\
\hline 4 & $\begin{array}{l}\text { The location and position of windows, } \\
\text { proximity of housing units in relation } \\
\text { to other units and 'mirror image' } \\
\text { arrangement of housing units result in } \\
\text { the visibility of internal spaces of the } \\
\text { housing units from outside. } \\
\text { Mirror image arrangement of housing } \\
\text { units allows visual exposure of internal } \\
\text { spaces. }\end{array}$ & $\begin{array}{l}\text { - Usage of curtains } \\
\text { - Closing the main door most of the time } \\
\text { which indirectly affects ven tilation of the } \\
\text { house } \\
\text { - Avoid overlooking into the neighbours' } \\
\text { houses } \\
\text { - Appropriate dressing } \\
\text { - Appropriate sitting }\end{array}$ \\
\hline 5 & $\begin{array}{l}\text { The overall arrangement of housing } \\
\text { units with defined territory in close } \\
\text { proximity } \\
\text { The lack of shared extemal spaces for } \\
\text { community interaction }\end{array}$ & $\begin{array}{l}\text { - Restricted interaction with neighbours } \\
\text { resulted in reduced community intimacy } \\
\text { - Tolerance of noise } \\
\text { - Acceptance of the lack of privacy as } \\
\text { something that the families must live } \\
\text { with given the constraint of terrace } \\
\text { housing environment }\end{array}$ \\
\hline
\end{tabular}

\section{The specifics of terrace housing modifications and their effects on Malay family and community}

Findings from the case studies indicate both positive and negative effects of terrace housing modification. There are four main modifications observed in most cases. The effects are also described below:

(a)Reorganisation and addition of spaces on ground floor 
Reorganisation and addition of spaces such as the living area, kitchen, porch and bedroom were the modifications which were mostly done at terrace housing. The addition of space(s) indirectly reorganised and redefined the spaces into the public and private spaces, relocates the staircase to the private domain of the house and allows better usage of the spaces for daily activities, interaction and provides privacy. However, the additions on the ground floor generally were beyond building setback, up to the rear boundary of the houses especially in the smaller terrace houses resulting in reduced distance between the houses and may affect the privacy of the families. However extension or addition of the porch area indirectly provides a place for interaction and privacy in the presence of guests.

The addition and reorganisation of bedrooms provide sufficient and functional bedrooms and separate sleeping places, privacy and other activities especially for adolescent children. The addition of bedrooms in some of the bigger houses provides privacy and accommodates visiting guests. The addition of a family or activity area was common as a result of reorganisation and addition of bedrooms on the first floor. The addition of bedroom may provide sufficient number of bedrooms, but compromised the comfort of the family in some cases due to the lack of natural lighting and ventilation after modification, and privacy due to the closer distance between houses at the rear.

Findings indicate that modification was particularly difficult on the first floor in the smaller housing units due to its width.

\section{(b) Addition of familyl activity area}

Addition of family area was observed in six of the case studies as a result of an addition of a new living area/ guest room. The addition of living room not only creates another space but indirectly reorganised the spaces into public and private space as mentioned earlier which provides the family a comfortable space for activities. This space was normally located in the first floor of the bigger terrace house and therefore allows members of the family privacy in the presence of guests.

\section{(c) Changes in the characteristics of windows and doors}

Findings indicate that changes in the characteristic of windows and doors were partly due to provide privacy to the family. Tinted glass windows in the bedrooms and louvre windows in the extended kitchen allow control of visual privacy and ventilation. The use of glass sliding door in the living area and casement or bay windows with tinted glass in the bedrooms was observed in all the case studies

\subsection{Conclusion}

Findings indicate that behavioural adaptation by the Malay families before modification was necessary to compensate the environmental constraint of the terrace houses. Behavioural adaptation was mainly to provide comfort for daily activity, privacy of the family and neighbours as well as control of social interaction. However some of the behavioural adaptations were not consistent with the cultural and religious belief of the Malays. Terrace housing modification was able to provide a more supportive living environment for the family. However, it also resulted in negative consequences such as reduced privacy, lack of ventilation and natural lighting. 


\section{References}

Altman, I. (1975). The Environment and Social Behavior: Privacy, Personal Space, Territoriality and Crowding. California: Brooks/Cole.

Ahmad Hariza, H., and Zaiton, A. R., Sharifah Norazizan, S. A. R. \& Nurizan, Y. (2006). Visual Privacy and Family Intimacy: A Case Study of Malay Inhabitant Living in Two-Storey Low Cost Housing. Journal of Environment and Planning $B, 33,301-318$.

Archea, J. (1977). The Place of Architectural Factors in Behavioural Theories of Privacy. Journal of Social Issues, 33(3), $116-137$.

Baron, R. A., and Byrne, D. (1991). Social Psychology - Understanding Human Interaction (2nd ed). London: Allyn and Bacon.

Bechtel, R. B., Marans, R. W., and Michelson, W. (Eds) (1990). Methods inEnvironmental and BehavioralResearch. Florida:RobertE. Krieger Publishing Company.

Booth, A., Edward, J. N., and Edwards, P. K. (1982). Housing Type, Stress and Family Relations. (Social Forces. $61(1), 244-257$.

Fatimah, A. (1994). Urbanisasi dan Kekeluargaan: Satu Kajian Kes Kelas Menengah Melayu di Kuala Lumpur, Unpublished Ph.D Thesis, University Malaya, Kuala Lumpur.

Flick, U. (1998). An Introduction to Qualitative Research. Thousand Oaks, California: Sage.

Guiliani, M. V., Rullo, G., and Bove, G. (1990). Socializing and Privacy Spaces Inside Homes. An Empirical Study. Proceedings $11^{\text {th }}$ International Conference of International Association of People Built Environment Study IAPS (pp. 129 - 138). Ankara, IAPS.

Hanson, S., and Hanson, P. (1993). The Geography of Everyday Life. In T. Garling \& R. G. Golledge (Eds). Behavior and Environment: Psychological and Geographical Approaches. (pp. 249- 269).

Lim. J.Y. (1987). The Malay House. Rediscovering Malaysia's Indigenous Shelter System. Pulau Pinang: Institut Masyarakat.

Lonner, W. J. \& Berry, L. W. (1986). Field Methods in Cross-cultural Research. Beverly Hills, California: Sage.

Mohamad Tajuddin, M. R. (2003, July 19). Terrace Living. Properties Times. New (traits 7imes. http://property.nst.com.my/?eekly/ PropertyTimes/viewpoint

Nasar, J. L. (1989). Symbolic Meanings of House Style. Environment and Behaviour, 21(3), 235 - 257.

Proshansky, H. M., Ittelson, W. H., and Rivlin, L. G. (1970). The Influence of the Physical Environment on Behaviour: SomeBasicAssumptions. In H. M. Proshansky, W. H. Ittelson, \&L. G. Rivlin.(Eds) Environmental Psychology: Man and his Physical Setting. (pp. 27 - 37). New York: Holt, Rinehart and Winston, Inc.

Rapoport, A (2005). Culture, Architecture and Design. Chicago: Locke Science Pub. Co.

Rapoport, A., \& Hardie, G. J. (1991). Cultural change analysis: Core concepts of housing for Tswana. In Tipple, A. G. \& Willis, K. G. (eds) (1991), Housing for the Poor in the Developing World. Pp 35-61. New York: Routledge.

Rapoport, A. (1981). Identity and Environment. A cross-cultural environment. In J. S. Duncan (Ed).Housing and 
Identity. (pp. 6 - 35). New York: Holmes \& Meier.

Rivlin, R. G. (2000). Reflections on the Assumptions and Foundations of Work in Environmental Psychology. In S. Wapner, J. Demick, T. Yamamoto, \& H. Minami (Eds). Theoretical Perspectives in Environment-Behavior Research: Underlying Assumptions, Research Problems, and Methodology. (pp. 51 - 60). New York: Kluwer Academic/ Plenum Publishers.

Vlatseas, S. (1990). A History of Malaysian Architecture. Singapore: Longman Singapore Publishers Pte. Ltd.

Wapner, S., Demick, J., Yamamoto, T., and Minami, H. (Eds). (2000). Theoretical Perspectives in EnvironmentBehavior Research: Underlying Assumptions, Research Problems, and Methodology. New York: Kluwer Academic/Plenum Publishers.

Yaakob, H. (1992). Keluarga Melayu Bandar, Satu Analysis Perubahan. Kuala Lumpur: Dewan Bahasa dan Pustaka. 